\title{
Monoclonal Band
}

National Cancer Institute

\section{Source}

National Cancer Institute. Monoclonal Band. NCI Thesaurus. Code C113808.

Monoclonal immunoglobulin or monoclonal light chain that is present in the serum and/or urine. It is the result of a clonal B-cell or plasma cell proliferation. 